\title{
A Basic Study on the Performance Evaluation of a Movable Light Shelf with a Rolling Reflector That Can Change Reflectivity to Improve the Visual Environment
}

\author{
Heangwoo Lee $\mathbb{D}$ \\ College of Design, Sangmyung University, Cheonan-si 03012, Chungcheongnam-do, Korea; 2hw@smu.ac.kr
}

Received: 25 October 2020; Accepted: 9 November 2020; Published: 11 November 2020

\begin{abstract}
In recent years, the need for comfortable visual environments in indoor spaces has increased energy use in buildings. There have been diverse studies on using a light shelf to solve this problem. It is an effective system that allows external natural light deep into indoor spaces through reflection. However, prior studies have used light shelves with a fixed reflectivity, and there are few studies on improving the visual environment through light shelf control. Therefore, this study proposes a movable light shelf with a rolling reflector that can change the reflectivity. To achieve these objectives, we conducted a performance evaluation of the system's ability to save energy and improve the visual environment. This study built a real scale testbed and conducted a performance evaluation by deriving values for lighting energy consumption, uniformity, and luminance contrast depending on the light shelf variables. We conclude that (1) the light shelf system achieved an energy savings of $13.6 \%$ and $5.7 \%$, respectively, compared to a fixed type light shelf, whose reflectivity cannot be changed, and a traditional movable light shelf; (2) in terms of improving the visual environment, results suggest that the visual environment could be improved using a light shelf by deriving light shelf variables that disturb indoor uniformity; and (3) the results verified glare generation conditions by deriving luminance contrast caused by the variables of light shelf angle and its reflectivity.
\end{abstract}

Keywords: light shelf; reflectivity; rolling type; visual comfort; performance evaluation

\section{Introduction}

Creating a comfortable environment in an indoor space requires controlling various equipment such as lighting, ventilation, air conditioning, and heating equipment, rapidly increasing building energy consumption [1-7]. According to the "2018 Renewable Energy Data Book" released by the Department of Energy in 2020 [8], the building sector accounts for $39.8 \%$ of total energy use. Thus, the importance of studies on building energy reduction and relevant technology development is gradually increasing. In the building sector, as much as $17 \%$ of the sector's total energy consumption is for lighting, according to "Electricity use in U.S. commercial buildings by major end uses", which was released by U.S. Energy Information Administration in 2012 [9]. The number of studies that examine natural lighting systems as a solution to this problem is rapidly increasing [10-12]. There have been diverse studies on the light shelf, an effective system that inflows external natural light deep into indoor spaces through reflection [13-27]. While it is advantageous to increase the light shelf reflector's reflectivity $[25,26]$, it can give the indoor space occupants an uncomfortable visual environment [27]. Nevertheless, prior studies on light shelves evaluated lighting performance, such as energy savings, by fixing the reflectivity of a reflector to a specific value [13-27]. Because the majority of the previous studies on light shelves focused on lighting performance only, there has been little information about whether light shelves provide an appropriate visual environment [28]. 
Building on this, the current study aims to develop a movable light shelf with a rolling reflector that can change its reflectivity, and further evaluate the reflector performance in consideration of lighting energy saving and glare of indoor spaces to verify its effectiveness.

\subsection{Experiment Equipment and Method}

As shown in Figure 1, a light shelf is a natural lighting system installed on a window that introduces natural light from the outside by reflecting the light shelf reflector and the ceiling surface of the indoor space, reducing energy used for lighting [29]. A light shelf can also create a comfortable visual environment by addressing the unbalanced distribution of illumination in indoor space by blocking excess natural light coming through a window. Light shelf variables that determine its performance include width, angle, height, and reflectivity. The light shelf may be an internal or external type depending on the installation location [30].

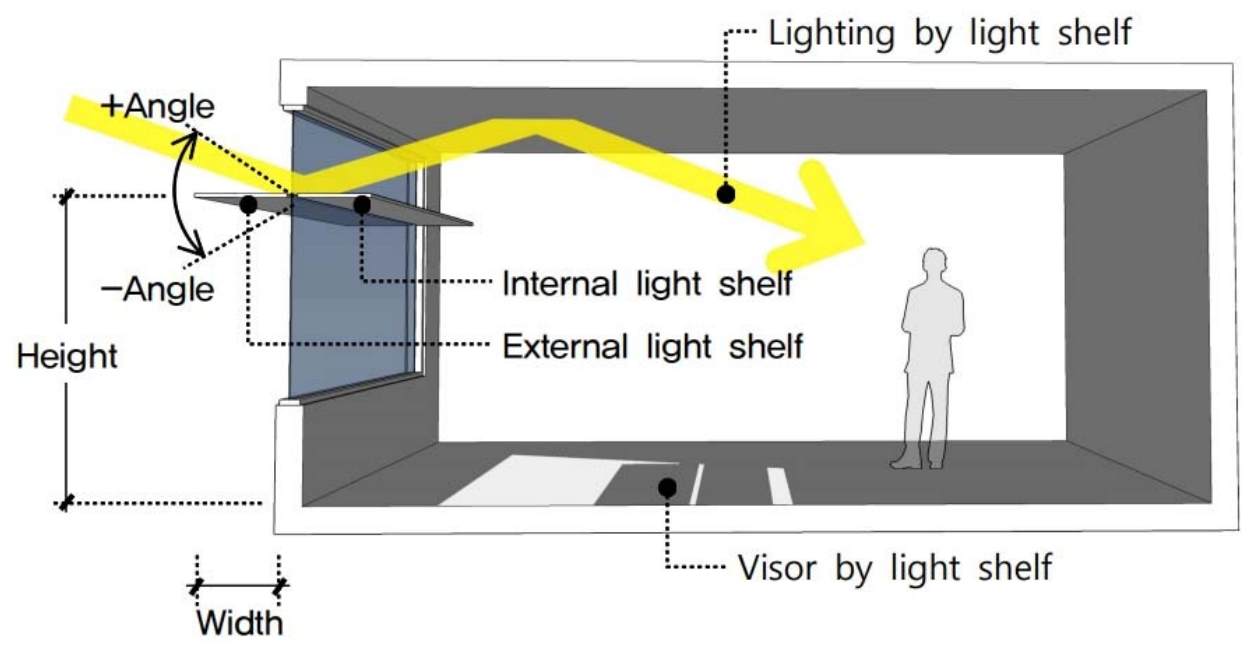

Figure 1. Light shelf concept and variables.

As shown in Table 1, there have been diverse studies on improving lighting performance and the indoor visual environment. As shown in Figure 2, many studies varied the light shelf's height and angle to improve lighting performance $[16,18,20-27]$. However, changing reflectivity was difficult because it required changing the light shelf's angle or height. Therefore, previous studies evaluated shelf performance with fixed reflectivity. Some studies $[16,21,25]$ considered a light shelf's specific reflectivity when designing and applying it. If light shelf reflectivity is high, the lighting performance improves because more light enters the room through reflection. However, in some cases, this can cause excessive glare for occupants [31]. Meanwhile, if a light shelf's reflectivity is low, the amount of natural light entering through the light shelf decreases, and the lighting performance deteriorates. In this case, the glare issue can be improved. Therefore, a light shelf's reflectivity is an important variable that can reduce lighting energy in an indoor space and improve its visual environment. Therefore, the development of a light shelf capable of changing its reflectivity is considered in the current analysis, which differentiates this research from prior studies. 
Table 1. Review of prior studies on the light shelf.

\begin{tabular}{|c|c|c|c|}
\hline Author & $\begin{array}{l}\text { Light Shelf Variables to } \\
\text { Improve Its Performance }\end{array}$ & $\begin{array}{l}\text { Light Shelf Reflectivity Setup } \\
\text { for Performance Evaluation }\end{array}$ & $\begin{array}{l}\text { Consideration of } \\
\text { Glare Caused by } \\
\text { Light Reflectivity }\end{array}$ \\
\hline Soler and Oteiza [13] & Fixed light shelf variables & Fixed to $91 \%$ & Not considered \\
\hline Soler and Oteiza [14] & Fixed light shelf variables & Fixed to $91 \%$ & Not considered \\
\hline Claros and Soler [15] & Fixed light shelf variables & Fixed to $84 \%$ & Not considered \\
\hline Claros and Soler [16] & $\begin{array}{l}\text { Width, angle, height, } \\
\text { reflectivity }\end{array}$ & $\begin{array}{l}\text { Performance evaluation was conducted by } \\
\text { considering light shelf reflectivity }(50 \%, 60 \% \text {, } \\
70 \%, 80 \%, 90 \%) \text {, but reflectivity was not changed } \\
\text { per case during performance evaluation. }\end{array}$ & Not considered \\
\hline Freewan et al. [17] & Fixed light shelf variables & Fixed to $85 \%$ & Not considered \\
\hline Raphael [18] & Angle & Fixed to $60 \%$ & Not considered \\
\hline Lim and Ahmad [19] & Height, shape & Fixed to $51.29 \%$ & Not considered \\
\hline Lim and Heng [20] & Shape, height, width & Fixed to $51.29 \%$ & Not considered \\
\hline Lee et al. [21] & $\begin{array}{l}\text { Perforation rate of a reflector, } \\
\text { angle, width }\end{array}$ & Fixed to $85 \%$ & Not considered \\
\hline $\begin{array}{l}\text { Berardi and Anaraki } \\
{[22]}\end{array}$ & Fixed light shelf variables & Fixed to $80 \%$ & Not considered \\
\hline Lee [23] & Angle & Fixed to $85 \%$ & Not considered \\
\hline Lee et al. [24] & Curvature, angle & Fixed to $85 \%$ & Not considered \\
\hline Meresi [25] & Width, angle, reflectivity & $\begin{array}{c}\text { Performance evaluation was conducted by } \\
\text { considering light shelf reflectivity }(50 \%, 60 \% \text {, } \\
70 \%, 80 \%, 90 \%) \text {, but reflectivity was not changed } \\
\text { per case during performance evaluation. }\end{array}$ & Not considered \\
\hline $\begin{array}{c}\text { Moazzeni and } \\
\text { Ghiabaklou [26] }\end{array}$ & Width, angle & Fixed to $90 \%$ & Not considered \\
\hline Mangkuto et al. [27] & Width, angle, reflectivity & $\begin{array}{l}\text { Performance evaluation was conducted by } \\
\text { considering light shelf reflectivity }(60 \%, 70 \% \text {, } \\
80 \%, 90 \%) \text {, but reflectivity was not changed per } \\
\text { case during performance evaluation. }\end{array}$ & Not considered \\
\hline
\end{tabular}

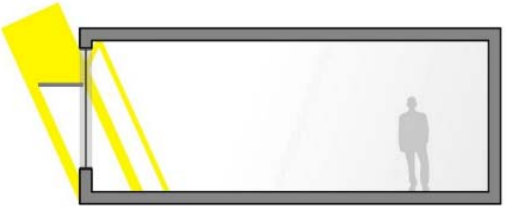

(a)

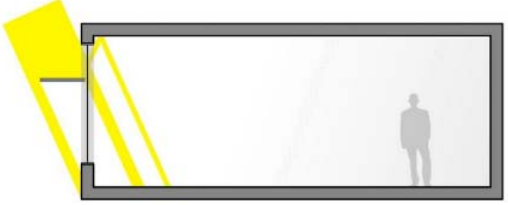

(c)

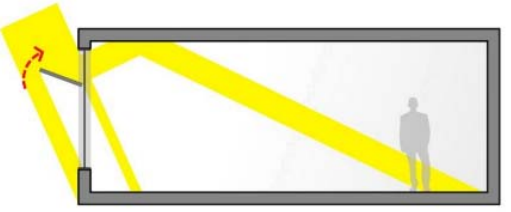

(b)

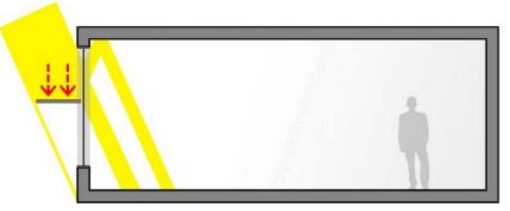

(d)

Figure 2. Natural light entering a room depending on light shelf angle and height: (a) natural light entering a room when light shelf angle is $0^{\circ} ;(\mathbf{b})$ natural light entering a room when light shelf angle is $20^{\circ}$; (c) natural light entering a room when light shelf height is $1.8 \mathrm{~m}$; (d) natural light entering a room when light shelf height is $1.5 \mathrm{~m}$.

\subsection{Review of Conditions for a Comfortable Visual Environment}

Achieving a comfortable visual environment calls for various requirements. However, in relation to the light shelves, we limited the requirements to three conditions, i.e., maintaining adequate indoor illumination, balancing indoor illumination, and solving the glare problem [32-36]. The details are as follows.

First, what is considered appropriate illumination of an indoor space depends on the application characteristics and conditions. It also varies by country. As shown in Table 2, the current study 
thus reviewed illumination standards for indoor spaces proposed in the U.S., Japan, and Korea. There are minimum, standard, and maximum values depending on the application type. Based on the illumination standards proposed in the U.S., Japan, and Korea, the most common value of 500 lx was used in the current study as an appropriate level of illumination for an indoor space for our performance evaluation. We excluded $600 \mathrm{~lx}$ because it was the maximum allowable range of indoor illumination standards in Japan and Korea. Second, a severely imbalanced illumination of an indoor space causes visual discomfort and decreases optical task efficiency [37]. Therefore, illumination uniformity was calculated, which represents illumination uniformity in an indoor space. The uniformity calculation is derived from the minimum to average illumination ratio or the minimum to maximum illumination ratio. Third, a glare means the visual discomfort caused by excessive luminance or luminance contrast, so it is desirable to reduce the value of luminance contrast in an indoor space. In particular, a glare due to luminance contrast usually occurs under the following conditions [38]. An unpleasant glare occurs due to luminance contrast when the luminance value of a specific object is 10 times or more than the average luminance in an observer's field of view. When the illumination value exceeds $25,000 \mathrm{~cd} / \mathrm{m}^{2}$ due to direct sun exposure or a light source in an observer's field of view, the excessive amount of light causes glare. In this case, a disability glare occurs regardless of the luminance contrast.

Table 2. Consideration of optimal indoor illuminance standards by country.

\begin{tabular}{|c|c|c|c|c|}
\hline \multirow[b]{2}{*}{$\begin{array}{l}\text { Illuminance Standard } \\
\text { (Country) }\end{array}$} & \multirow[b]{2}{*}{ Type of Activity } & \multicolumn{3}{|c|}{ Scope (lx) } \\
\hline & & $\begin{array}{l}\text { Minimum } \\
\text { Allowed } \\
\text { Illumination }\end{array}$ & $\begin{array}{c}\text { Standard } \\
\text { Allowed } \\
\text { Illumination }\end{array}$ & $\begin{array}{l}\text { Maximum } \\
\text { Allowed } \\
\text { Illumination }\end{array}$ \\
\hline $\begin{array}{l}\text { IES (Illuminating Engineering Society) } \\
\text { (USA) [34] }\end{array}$ & $\begin{array}{c}\text { General } \\
\text { (performance of }\end{array}$ & 500 & 750 & 1000 \\
\hline $\begin{array}{l}\text { JIS (Japan Industrial Standard) Z } 9110 \\
\text { (Japan) [35] }\end{array}$ & visual tasks of & 300 & 500 & 600 \\
\hline $\begin{array}{l}\text { KS (Korean Industrial Standards) A } \\
3011 \text { (Republic of Korea) [36] }\end{array}$ & & 300 & 400 & 600 \\
\hline
\end{tabular}

\section{Method}

\subsection{Proposal of a Light Shelf with a Rolling Reflector With Varied Reflectivity}

As shown in Figure 3, a light shelf with a rolling reflector that can change its reflectivity was proposed.

First, as shown in Figure 3, the proposed light shelf has connected reflective films with $70 \%$, $85 \%$, and $97 \%$ reflectivity, respectively. The film can be rolled by two axes to change reflectivity. The reflectivity values of $70 \%$ and $85 \%$ were chosen based on prior studies $[13,14,18,22-24]$, and the reflectivity value of $97 \%$ was the reflective film manufacturer's specification [39]. This is the result of an adjustment because lighting performance increases with reflectivity.

Second, two motors are used for the light shelf, i.e., a motor to control the light shelf's angle and a motor used for rolling to change reflectivity. As a result, the light shelf is thicker than a typical light shelf because it has two motors and an additional apparatus that helps the reflective films rolling. Also, the light shelf's width is higher than that of a typical light shelf due to its driving part. In other words, a light shelf with a rolling reflector that can change reflectivity must be wider to achieve the same reflective area as a typical light shelf. This proposed light shelf's thickness and width can be changed depending on the reflective surface width. 


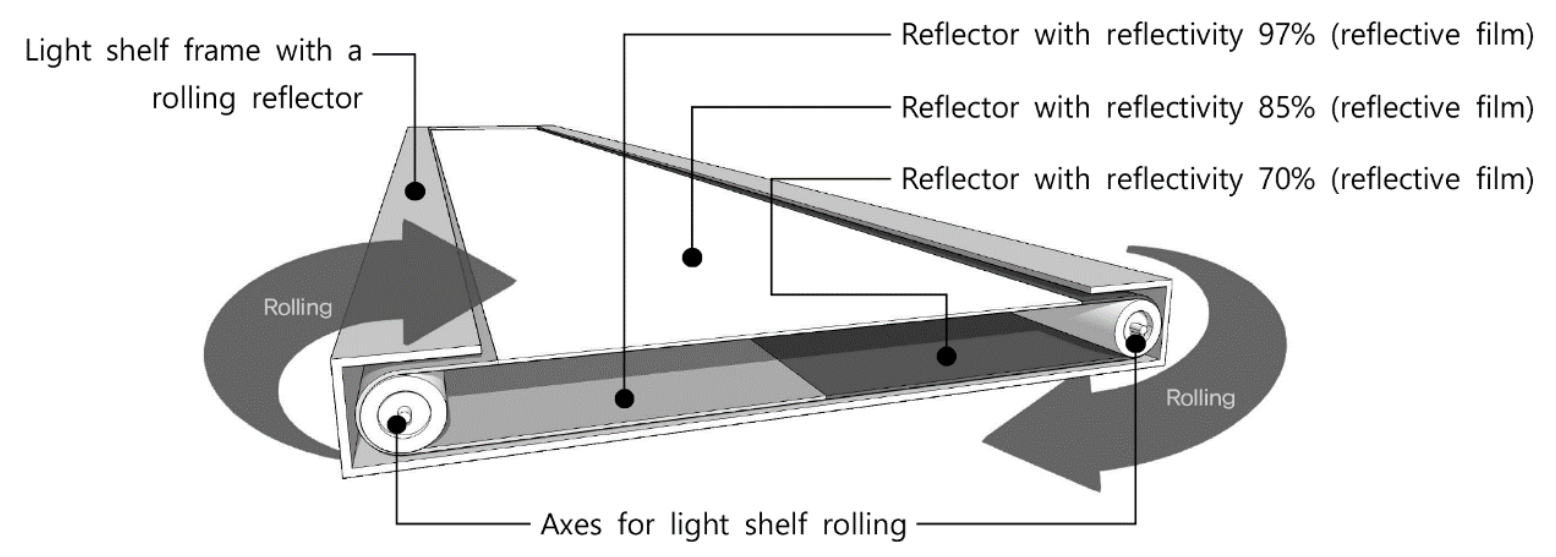

Figure 3. Internal structure of a light shelf with a rolling reflector.

Third, the control of the proposed light shelf with a rolling reflector that can change its reflectivity and its appropriate variables were based on the following procedure. Before an occupant enters the room, the light shelf is configured at an angle of $-10^{\circ}$ and a reflectivity of $70 \%$. When the occupant enters, the angle is increased by $10^{\circ}$ from its initial value. At a specific angle, its reflectivity is changed to $70 \%, 85 \%$, and $97 \%$ to collect indoor illumination information. Based on the collected information, the light shelf automatically returns to an angle that can increase the visual environment's comfort. The current study aims to improve indoor illuminance uniformity and luminance contrast for the optimal indoor visual environment while giving the highest priority to lighting energy saving.

\subsection{Configuration of Performance Evaluation Environment}

In the current investigation, a real-scale testbed was constructed, as shown in Table 3 and Figure 4, to evaluate the movable light shelf with a rolling reflector that can change reflectivity. The details are as follows.

First, the dimensions of the testbed constructed for the performance evaluation is $4.9 \mathrm{~m}(\mathrm{~W}) \times 6.6 \mathrm{~m}(\mathrm{D}) \times 2.5 \mathrm{~m}(\mathrm{H})$, and the reflectivity of the indoor space is set to $86 \%$ for the ceiling, $46 \%$ for the wall and $25 \%$ for the floor. The skylight on which the light shelf is installed is $1.9 \mathrm{~m}(\mathrm{~W}) \times 1.7 \mathrm{~m}(\mathrm{H})$ with pair glass applied, and the window transmissivity is $80 \%$.

Second, an external environment for performance evaluation was developed by constructing an artificial solar irradiation apparatus, as shown in Figure 4; Figure 5, outside the installed window. Artificial solar irradiation apparatus used in the current study can simulate the sun's brightness and altitude by controlling the light amount, height, and angle of a light source. In particular, the artificial solar irradiation apparatus is an artificial solar irradiation apparatus of ASTM (American Society for Testing and Materials) E927-85 standard [40] A grade, so it is possible to derive valid experimental results. However, the mechanical characteristics of the artificial solar irradiation apparatus prevented it from simulating the sun's azimuth angle. Its azimuth angle was limited to the south direction. When creating an external environment using the artificial solar irradiation system, the altitude and external illuminance were set for the summer, middle season, and winter, as shown in Table 4, based on the related studies performed in Seoul, Korea [26].

Third, in the current study, LED-type lights, which support nine-step dimming control, including lighting OFF, were installed at four locations to verify the light shelf's lighting energy saving performance. Figure 6 shows the light distribution curve and conical illuminance according to the LED lighting's nine-step dimming control status. The location of LED-type lights was determined based on the IES (Illuminating Engineering Society) four-point method [33]. Further, an energy monitoring system was installed to measure lighting energy consumption, and its measurement error rate is within $2 \%$. 
Fourth, eight indoor illuminance sensors were installed to measure lighting control and indoor illumination distribution. The illumination sensors' location was set to $4.4 \mathrm{~m}$ from the skylight, as shown in Figure 5, based on the study [41], which reported that $4.4 \mathrm{~m}$ is most suitable to measure the most representative illuminance value of an indoor space. The illumination sensor was located $0.75 \mathrm{~m}$ from the floor surface because it was the height of a typical work surface.

Table 3. Overview of testbed.

\begin{tabular}{|c|c|}
\hline \multicolumn{2}{|c|}{ Room Size and Reflexibility } \\
\hline Size & $4.9 \mathrm{~m}(\mathrm{~W}) \times 6.6 \mathrm{~m}(\mathrm{D}) \times 2.5 \mathrm{~m}(\mathrm{H})$ \\
\hline Reflexibility & Ceiling $86 \%$, Wall 46\%, Floor 25\% \\
\hline \multicolumn{2}{|c|}{ Window size and material } \\
\hline Size & $1.9 \mathrm{~m}(\mathrm{~W}) \times 1.7 \mathrm{~m}(\mathrm{H})$ \\
\hline Type & Double glazed $12 \mathrm{~mm} 12 \mathrm{~mm}$ (3 Clean +6 Air +3 Clean $)$ \\
\hline Transmissivity & $80 \%$ \\
\hline \multicolumn{2}{|r|}{ Lighting } \\
\hline Type & Eight-level dimming (LED-type) 4ea \\
\hline Dimensions (mm) & $600 \times 600$ \\
\hline Dimming range & $10-100 \%$ \\
\hline Energy consumption for phased light dimming & $\begin{array}{l}0 \mathrm{kWh} \text { (OFF), } 12.3 \mathrm{kWh} \text { (Dimming Level 1), 18.3 kWh (Dimming } \\
\text { Level 2), } 22.0 \mathrm{kWh} \text { (Dimming Level 3), } 27.7 \mathrm{kWh} \text { (Dimming Level 4), } \\
34.0 \mathrm{kWh} \text { (Dimming Level 5), 38.5 kWh (Dimming Level 6), } \\
42.6 \mathrm{kWh} \text { (Dimming Level 7), and 50.8 kWh (Dimming Level 8) }\end{array}$ \\
\hline \multicolumn{2}{|r|}{ Illuminance sensor } \\
\hline $\begin{array}{l}\text { Sensing element } \\
\text { Precision }\end{array}$ & $\begin{array}{l}\text { Silicon photosensor, with filter } \\
\qquad \pm 3 \%\end{array}$ \\
\hline \multicolumn{2}{|c|}{ Artificial solar light radiation apparatus } \\
\hline $\begin{array}{c}\text { Precision of solar light radiation } \\
\text { Directions }\end{array}$ & $\begin{array}{l}\text { Grade A (according to ASTM E927-85) } \\
\text { South aspect }\end{array}$ \\
\hline \multicolumn{2}{|c|}{ Energy monitoring system } \\
\hline Model & SPM-141 \\
\hline Measurement capacity & Single-phase (220 V, 1-50 A) \\
\hline Error rate & Within $2.0 \%$ \\
\hline
\end{tabular}

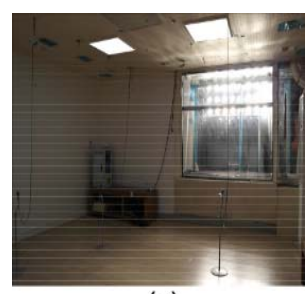

(a)

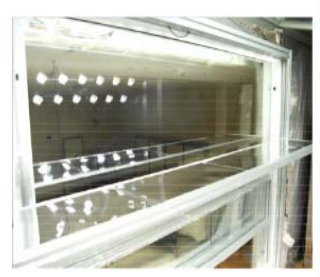

(e)

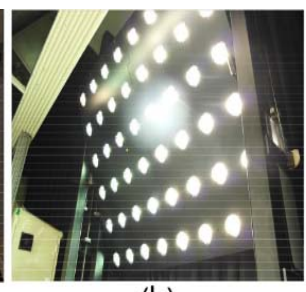

(b)

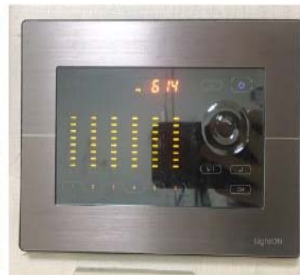

(f)

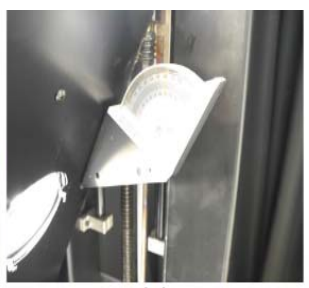

(c)

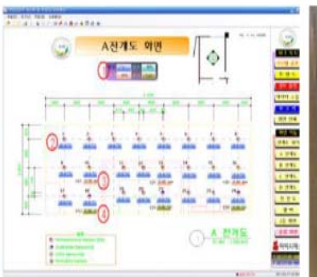

(g)

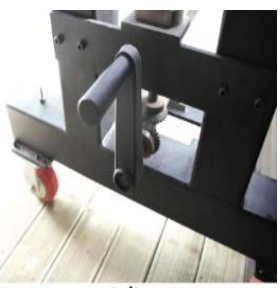

(d)

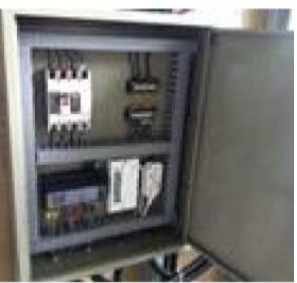

(h)

Figure 4. Overview of testbed and measurement apparatus: (a) performance evaluation testbed; (b) artificial solar irradiation apparatus; (c) control of light source angle of artificial solar irradiation apparatus; (d) lever to control light source altitude of artificial solar irradiation apparatus; (e) installed light shelf; (f) eight-level lighting controller; (g) illuminance sensor monitoring server; (h) energy monitoring system. 


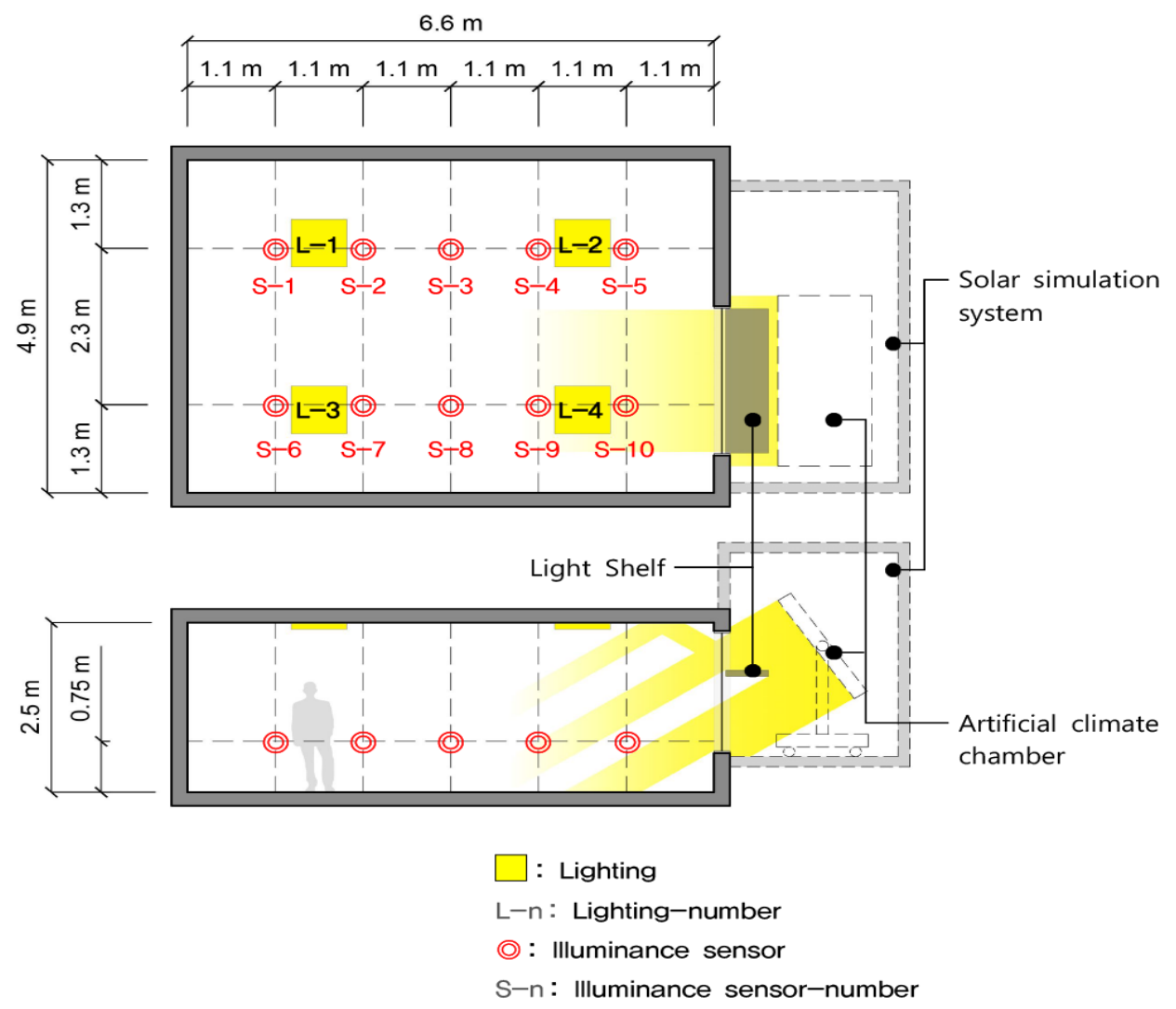

Figure 5. Cross-section and plane of testbed and sensor location.

Table 4. Configuration of meridian altitude of the sun and external illuminance for summer, middle season, and winter.

\begin{tabular}{ccc}
\hline Season & Meridian Altitude & External Illuminance (1x) \\
\hline Summer & 76.5 & 80,000 \\
Middle season & 52.5 & 60,000 \\
Winter & 29.5 & 30,000 \\
\hline
\end{tabular}

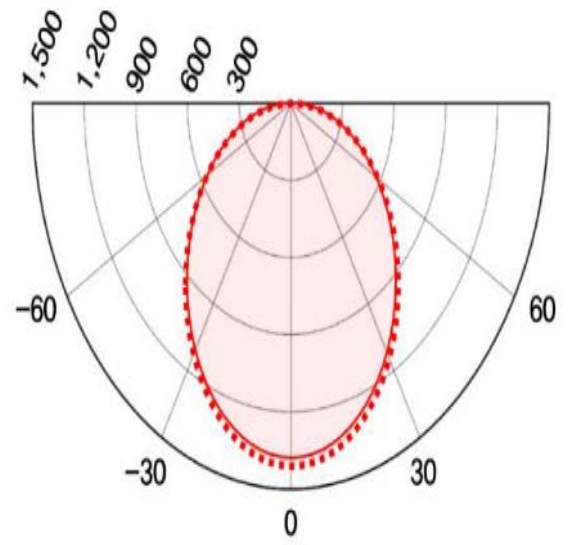

(a)

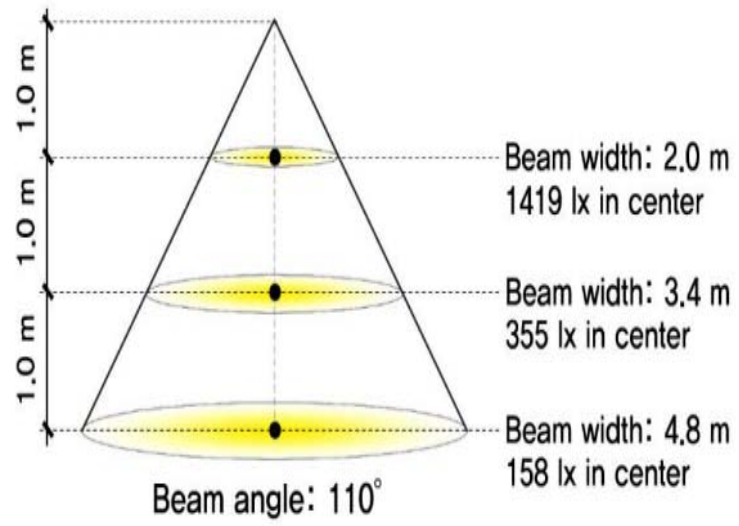

(b)

Figure 6. Light distribution curve and conical illuminance of lighting: (a) conical illuminance; (b) light distribution. 


\subsection{Performance Evaluation Method}

In the current study, a performance evaluation of the lighting energy saving, uniformity, and glare of a movable light shelf with a rolling reflector that can change its reflectivity was conducted based on the following method.

First, three different cases for the performance evaluation were developed to verify the effectiveness of a light shelf whose reflectivity can be changed (see Table 5). The height of the light shelf for performance evaluation was set to $1.8 \mathrm{~m}$ from the floor of indoor space by considering relevant studies [28] and occupants' eye level. Case 1 is a type with a fixed light shelf angle of $0^{\circ}$, and Case 2 is a movable type with a light shelf angle from $-10^{\circ}$ to $30^{\circ}$ with $10^{\circ}$ steps. From these two cases, lighting performance and glare were compared. The reflectivity of the light shelves used in Case 1 and Case 2 was set to $85 \%$. The light shelf with a rolling reflector that can change its reflectivity is used in Case 3. The light shelf with a rolling reflector that can change its reflectivity (Case 3) is wider than that of typical light shelves used in Case 1 and Case 2 because it incorporates a rolling-type driving part to change its reflectivity. However, the actual reflective area of Case 3 is the same as for Case 1 and Case 2 .

Table 5. Cases for performance evaluation.

\begin{tabular}{cccccc}
\hline \multirow{2}{*}{ Case } & \multicolumn{5}{c}{ Light Shelf Variables } \\
\cline { 2 - 6 } & Type & Height & Angle & Width & Reflectivity \\
\hline 1 & & & Fixed to $0^{\circ}$ & $0.3 \mathrm{~m}$ & Fixed to $85 \%$ \\
2 & External light shelf & \multirow{2}{*}{$1.8 \mathrm{~m}$} & $-10^{\circ}-30^{\circ}\left(10^{\circ}\right.$ steps $)$ & $0.3 \mathrm{~m}$ & Fixed to $85 \%$ \\
3 & & & & $0.38 \mathrm{~m}$ & Changeable to $70 \%, 85 \%$, and $97 \%$ \\
\hline
\end{tabular}

Second, the lighting control level and lighting energy consumption to maintain $500 \mathrm{~lx}$, the appropriate illumination of an indoor space, were derived by analyzing illumination distribution in an indoor space for the three cases defined above. Lighting control is based on the following procedure. First of all, the lights 1, 2, 3, and 4 were linked to the illumination sensors 2, 4, 7, 9, respectively, for lighting dimming control. It enabled lighting control by measuring the values of illumination sensors 2, 4, 7, and 9. A lighting control system, based on illumination sensor information, was built in cooperation with Samsung SDS in Seoul, Korea. The lighting dimming control was configured such that there was no separate lighting control if all the measured values of illumination sensors 2, 4, 7, 9 are $500 \mathrm{~lx}$ or more, and there was lighting dimming control only when there was a measured value less than $500 \mathrm{~lx}$. In this case, the dimming step increased step-by-step for a light linked to the sensor with a minimum value among the measured values of illumination sensors $2,4,7,9$. The lighting dimming control terminated when all the illumination sensors met $500 \mathrm{~lx}$ during this process. However, suppose $500 \mathrm{~lx}$ could not be measured at the sensor with a minimum illumination value, even after the eight-step dimming control. In that case, it was necessary to increase the dimming level for the light closest to the sensor and monitor illumination sensor information again. For example, suppose $300 \mathrm{~lx}$ was the minimum illumination value measured among illuminance sensors 2, 4, 7, and 9, and it was measured at illumination sensor 2 . Then it was necessary to start dimming control for light 1 , which was connected to illumination sensor 2 , and check if all the measured values of the indoor illumination sensors met $500 \mathrm{~lx}$ while increasing the dimming level of light 1 . If the indoor illumination sensor did not meet 500 lx even after dimming step 8 of light 1, the dimming step for light 3 was increased, which was closest to light 1 , and we checked if the indoor measured values illumination sensors met $500 \mathrm{~lx}$. This process was repeated, and the lighting dimming control terminated when all the indoor illuminance sensors met $500 \mathrm{~lx}$. The lighting energy consumption was derived based on the lighting dimming control steps at this time. The lighting energy consumption was derived based on one hour in the south direction, and day 15, day 30, and day 15 were set for the summer, middle season, and winter, respectively; these are reflected in the performance evaluation.

Third, this study derived an index for illuminance uniformity in an indoor space and applied the minimum illumination ratio to the average illumination index. 
Fourth, as shown in Figure 7, luminance values for 39 points were measured by considering the human viewing angle. The luminance of the light shelf reflector was also measured in order to obtain an average value by measuring eight points on the light shelf reflector. However, luminance could not be measured because measurement positions were not accessible when the light shelf angle was $0^{\circ}$ and $-10^{\circ}$, so luminance was measured on the window's glass surface at the top of the light shelf. The luminance measurement location was set at $1.5 \mathrm{~m}$ from the floor and $5.5 \mathrm{~m}$ away from the skylight to consider the indoor space's depth. The glare was analyzed based on the measured luminance and contrast values. The luminance measurement equipment is a handy type of high-precision luminance meter, the detailed specifications of which are shown in Table 6.

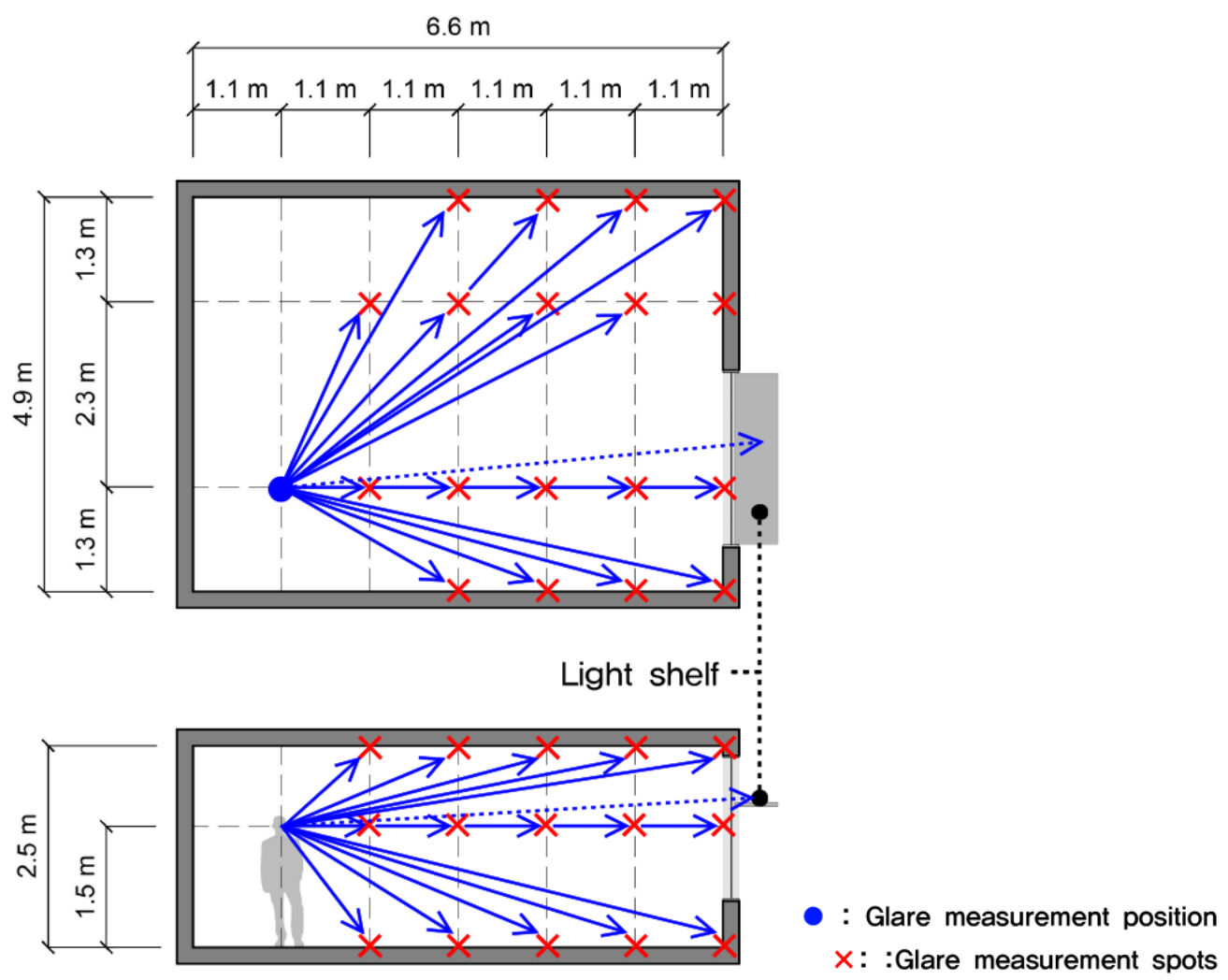

Figure 7. Glare measurement position and measurement spots.

Table 6. Specifications and image of luminance meter.

\begin{tabular}{|c|c|c|}
\hline & Details & Product and Measurement Images \\
\hline Model & Luminance Meter LS-100 (Tokyo, Japan) & \\
\hline Type & $\begin{array}{c}\text { SLR spot luminance meter for measuring light source } \\
\text { and surface brightness }\end{array}$ & \\
\hline Measuring range & FAST: $0.001-299,900 \mathrm{~cd} / \mathrm{m}^{2}$, SLOW: $0.001-49,990 \mathrm{~cd} / \mathrm{m}^{2}$ & \\
\hline Angle of view & $9^{\circ}$ & \\
\hline Accuracy & $\pm 2 \% \pm 2$ digits of displayed value & \\
\hline
\end{tabular}

Fifth, the current study derived the process of natural light being reflected and flowing into a room depending on the light shelf angle and uses it as data to analyze the light shelf performance evaluation results. The natural light's inflow process through the light shelf was visualized using AutoCAD (Autodesk Inc., San Rafael, CA, USA) by calculating the incidence angle and reflection angle. However, the scattered reflection was excluded from the visualization and processed as a kind of mirror reflection. 


\section{Result and Discussion}

\subsection{Performance Evaluation Results}

The performance evaluation results for the three cases and environmental factors are presented in Tables 7-10.

Table 7. Performance evaluation results of Case 1 and Case 2: analysis of uniformity, glare, and lighting energy consumption.

\begin{tabular}{|c|c|c|c|c|c|c|c|c|c|c|}
\hline \multirow[t]{2}{*}{ Season } & \multicolumn{2}{|c|}{ Light Shelf } & \multicolumn{2}{|c|}{$\begin{array}{l}\text { Illumination } \\
\text { Sensor (lx) }\end{array}$} & \multirow[t]{2}{*}{$\mathbf{U}$} & \multicolumn{2}{|c|}{$\begin{array}{l}\text { Luminance } \\
\left(\mathrm{cd} / \mathrm{m}^{3}\right)\end{array}$} & \multirow[t]{2}{*}{$\mathbf{L}$} & \multirow{2}{*}{$\begin{array}{l}\text { Lighting Dimming } \\
\text { Control: Light Number } \\
\text { (Dimming Level) }\end{array}$} & \multirow{2}{*}{$\begin{array}{l}\text { Lighting Energy } \\
\text { Consumption } \\
(\mathbf{k W h})\end{array}$} \\
\hline & A & $\mathrm{R}(\%)$ & Min. & Ave. & & Max. & Ave. & & & \\
\hline \multirow{3}{*}{ Summer } & 0 & 85 & 73.6 & 372.3 & 0.198 & 3111.1 & 711.1 & 4.4 & $1(8)+3(8)+2(5)$ & 2.034 \\
\hline & 10 & 85 & 78.5 & 387.5 & 0.203 & 9224.7 & 1169.4 & 7.9 & $1(8)+3(8)+2(5)$ & 2.034 \\
\hline & 20 & 85 & 81.9 & 391.9 & 0.209 & 9294.4 & 1185.3 & 7.8 & $1(8)+3(8)+2(4)$ & 1.939 \\
\hline \multirow{5}{*}{$\begin{array}{l}\text { Middle } \\
\text { season }\end{array}$} & -10 & 85 & 120.2 & 346.8 & 0.347 & 4606.0 & 1202.6 & 3.8 & $1(8) \rightarrow 3(7)$ & 2.802 \\
\hline & 0 & 85 & 125.4 & 355.7 & 0.353 & 4918.0 & 1269.9 & 3.9 & $1(8) \rightarrow 3(6)$ & 2.679 \\
\hline & 10 & 85 & 131.5 & 359.1 & 0.366 & $12,539.7$ & 1840.0 & 6.8 & $1(8) \rightarrow 3(5)$ & 2.544 \\
\hline & 20 & 85 & 139.9 & 369.1 & 0.379 & $12,588.6$ & 1809.2 & 7.0 & $1(8) \rightarrow 3(5)$ & 2.544 \\
\hline & 30 & 85 & 149.6 & 469.7 & 0.318 & $17,659.0$ & 1865.2 & 9.5 & $1(8) \rightarrow 3(4)$ & 2.354 \\
\hline Winter & -10 & 85 & 249.5 & 4928.2 & 0.051 & $11,247.8$ & 1959.7 & 5.7 & $1(5)$ & 0.510 \\
\hline
\end{tabular}

Note; A: Angle, R: Reflectivity, Min.: Minimum Ave.: Average, U: Uniformity factor, L: Luminance contrast.

Table 8. Light shelf angle for lighting energy saving and total lighting energy consumption for Case 1 and Case 2.

\begin{tabular}{|c|c|c|c|c|}
\hline Case & Season & $\begin{array}{l}\text { Light Shelf Angle } \\
\text { for Energy Saving }\end{array}$ & $\begin{array}{c}\text { Lighting Energy } \\
\text { Consumption (kWh) }\end{array}$ & $\begin{array}{l}\text { Total Lighting Energy } \\
\text { Consumption (kWh) }\end{array}$ \\
\hline \multirow{3}{*}{1} & Summer & & 2.034 & \multirow{3}{*}{5.290} \\
\hline & Middle season & Fixed to $0^{\circ}$ & 2.679 & \\
\hline & Winter & & 0.577 & \\
\hline \multirow{3}{*}{2} & Summer & $30^{\circ}$ & 1.855 & \multirow{3}{*}{4.624} \\
\hline & Middle season & $30^{\circ}$ & 2.354 & \\
\hline & Winter & $10^{\circ}$ & 0.415 & \\
\hline
\end{tabular}

First, as shown in Table 8, the lighting energy consumption maintained an appropriate indoor illumination of $500 \mathrm{~lx}$ for an external type light shelf with an angle of $0^{\circ}$ and a reflectivity of $85 \%$ (Case 1$)$ $5.290 \mathrm{kWh}$. On the other hand, the appropriate angles of a movable external light shelf with $85 \%$ reflectivity (Case 2) for energy saving were $30^{\circ}, 30^{\circ}$, and $10^{\circ}$ for the summer, middle season, and winter, respectively, and the energy consumption was $4.624 \mathrm{kWh}$. Meanwhile, the angle and reflectivity, only for energy saving, of the light shelf with a rolling reflector that can change its reflectivity (Case 3) were the same as an angle of $30^{\circ}$ and a reflectivity of $97 \%$ for the summer, middle season and winter, and the lighting energy consumption was $4.288 \mathrm{kWh}$. 
Table 9. Performance evaluation results of Case 3: analysis of uniformity, glare, and lighting energy consumption.

\begin{tabular}{|c|c|c|c|c|c|c|c|c|c|c|}
\hline \multirow[t]{2}{*}{ Season } & \multicolumn{2}{|c|}{ Light Shelf } & \multicolumn{2}{|c|}{$\begin{array}{l}\text { Illumination } \\
\text { Sensor (lx) }\end{array}$} & \multirow[t]{2}{*}{$\mathbf{U}$} & \multicolumn{2}{|c|}{$\begin{array}{l}\text { Luminance } \\
\qquad\left(\mathrm{cd} / \mathrm{m}^{3}\right)\end{array}$} & \multirow[t]{2}{*}{$\mathbf{L}$} & \multirow{2}{*}{$\begin{array}{l}\text { Lighting Dimming } \\
\text { Control: Light Number } \\
\text { (Dimming Level) }\end{array}$} & \multirow{2}{*}{$\begin{array}{l}\text { Lighting Energy } \\
\text { Consumption (kWh) }\end{array}$} \\
\hline & A & $\mathbf{R}(\%)$ & Min. & Ave. & & Max. & Ave. & & & \\
\hline \multirow{15}{*}{ Summer } & \multirow{3}{*}{-10} & 70 & 54.3 & 280.3 & 0.194 & 2273.3 & 548.1 & 4.1 & $1(8)+3(8)+2(6)$ & 2.102 \\
\hline & & 85 & 67.4 & 341.8 & 0.197 & 2879.7 & 678.1 & 4.2 & $1(8)+3(8)+2(5)$ & 2.034 \\
\hline & & 97 & 76.1 & 384.0 & 0.198 & 3235.4 & 745.9 & 4.3 & $1(8)+3(8)+2(5)$ & 2.034 \\
\hline & \multirow{3}{*}{0} & 70 & 58.6 & 300.6 & 0.195 & 2482.9 & 571.8 & 4.3 & $1(8)+3(8)+2(6)$ & 2.102 \\
\hline & & 85 & 72.7 & 366.6 & 0.198 & 3145.3 & 707.5 & 4.4 & $1(8)+3(8)+2(5)$ & 2.034 \\
\hline & & 97 & 82.2 & 411.9 & 0.200 & 3533.8 & 778.3 & 4.5 & $1(8)+3(8)+2(4)$ & 1.939 \\
\hline & \multirow{3}{*}{10} & 70 & 62.7 & 313.0 & 0.200 & 7362.2 & 940.5 & 7.8 & $1(8)+3(8)+2(5)$ & 2.034 \\
\hline & & 85 & 77.8 & 381.7 & 0.204 & 9326.2 & 1163.6 & 8.0 & $1(8)+3(8)+2(4)$ & 1.939 \\
\hline & & 97 & 88.1 & 428.9 & 0.205 & 10642.8 & 1280.0 & 8.3 & $1(8)+3(8)+2(3)$ & 1.855 \\
\hline & \multirow{3}{*}{20} & 70 & 65.3 & 316.6 & 0.206 & 7417.8 & 953.2 & 7.8 & $1(8)+3(8)+2(5)$ & 2.034 \\
\hline & & 85 & 81.0 & 386.1 & 0.210 & 9396.6 & 1179.4 & 8.0 & $1(8)+3(8)+2(4)$ & 1.939 \\
\hline & & 97 & 91.8 & 433.8 & 0.212 & 10723.2 & 1297.3 & 8.3 & $1(8)+3(8)+2(3)$ & 1.855 \\
\hline & \multirow{3}{*}{30} & 70 & 71.9 & 309.6 & 0.232 & 7832.7 & 992.0 & 7.9 & $1(8)+3(8)+2(5)$ & 2.034 \\
\hline & & 85 & 89.3 & 377.6 & 0.236 & 9922.2 & 1227.4 & 8.1 & $1(8)+3(8)+2(3)$ & 1.855 \\
\hline & & 97 & 101.3 & 424.2 & 0.239 & 11323.0 & 1350.1 & 8.4 & $1(8)+3(8)+2(2)$ & 1.799 \\
\hline \multirow{15}{*}{$\begin{array}{l}\text { Middle } \\
\text { season }\end{array}$} & \multirow{3}{*}{-10} & 70 & 96.0 & 280.1 & 0.343 & 3676.1 & 967.1 & 3.8 & $1(8)+3(8)+2(1)$ & 3.419 \\
\hline & & 85 & 118.4 & 341.6 & 0.347 & 4656.7 & 1196.6 & 3.9 & $1(8)+3(7)$ & 2.802 \\
\hline & & 97 & 133.7 & 383.8 & 0.348 & 5314.1 & 1316.3 & 4.0 & $1(8)+3(5)$ & 2.544 \\
\hline & \multirow{3}{*}{0} & 70 & 100.6 & 286.3 & 0.351 & 3925.0 & 1021.3 & 3.8 & $1(8)+3(8)$ & 3.049 \\
\hline & & 85 & 124.1 & 349.1 & 0.355 & 4972.1 & 1263.6 & 3.9 & $1(8)+3(6)$ & 2.679 \\
\hline & & 97 & 140.2 & 392.2 & 0.357 & 5674.0 & 1390.0 & 4.1 & $1(8)+3(4)$ & 2.354 \\
\hline & \multirow{3}{*}{10} & 70 & 104.2 & 289.5 & 0.360 & 10007.8 & 1479.7 & 6.8 & $1(8)+3(8)$ & 3.049 \\
\hline & & 85 & 129.5 & 353.1 & 0.367 & 12677.6 & 1830.8 & 6.9 & $1(8)+3(5)$ & 2.544 \\
\hline & & 97 & 147.8 & 396.7 & 0.373 & 14467.4 & 2013.9 & 7.2 & $1(8)+3(4)$ & 2.354 \\
\hline & \multirow{3}{*}{20} & 70 & 111.2 & 297.9 & 0.373 & 10046.9 & 1455.0 & 6.9 & $1(8)+3(7)$ & 2.802 \\
\hline & & 85 & 138.2 & 363.3 & 0.380 & 12727.1 & 1800.2 & 7.1 & $1(8)+3(4)$ & 2.354 \\
\hline & & 97 & 149.6 & 391.1 & 0.382 & 14923.9 & 1980.2 & 7.5 & $1(8)+3(4)$ & 2.354 \\
\hline & \multirow{3}{*}{30} & 70 & 118.9 & 378.9 & 0.314 & 14093.5 & 1500.0 & 9.4 & $1(8)+3(7)$ & 2.802 \\
\hline & & 85 & 147.6 & 462.1 & 0.319 & 17853.2 & 1855.9 & 9.6 & $1(8)+3(4)$ & 2.354 \\
\hline & & 97 & 159.9 & 498.5 & 0.321 & 20673.7 & 2041.5 & 10.1 & $1(8)+3(2)$ & 2.074 \\
\hline & & 70 & 202.2 & 3962.6 & 0.051 & 8865.9 & 1600.0 & 5.5 & $1(5)$ & 0.510 \\
\hline & -10 & 85 & 247.3 & 4853.3 & 0.051 & 11247.8 & 1959.7 & 5.7 & $1(4)$ & 0.415 \\
\hline & & 97 & 280.8 & 5481.4 & 0.051 & 12769.6 & 2213.3 & 5.8 & 1(4) & 0.415 \\
\hline & & 70 & 207.4 & 4052.1 & 0.051 & 9070.1 & 1624.2 & 5.6 & $1(5)$ & 0.510 \\
\hline & 0 & 85 & 253.6 & 4962.9 & 0.051 & 11472.6 & 1989.3 & 5.8 & $1(4)$ & 0.415 \\
\hline & & 97 & 287.9 & 5605.2 & 0.051 & 13078.8 & 2251.4 & 5.8 & $1(4)$ & 0.415 \\
\hline Winter & & 70 & 215.3 & 4130.9 & 0.052 & 10154.0 & 1590.2 & 6.4 & $1(5)$ & 0.510 \\
\hline & 10 & 85 & 263.3 & 5059.4 & 0.052 & 12843.6 & 1947.7 & 6.6 & $1(4)$ & 0.415 \\
\hline & & 97 & 298.9 & 5714.1 & 0.052 & 14732.4 & 2204.3 & 6.7 & $1(4)$ & 0.415 \\
\hline & & 70 & 219.1 & 4246.1 & 0.052 & 14746.0 & 1672.4 & 8.8 & $1(5)$ & 0.510 \\
\hline & 20 & 85 & 268.0 & 5200.6 & 0.052 & 18432.5 & 2048.3 & 9.0 & $1(4)$ & 0.415 \\
\hline & & 97 & 304.3 & 5873.6 & 0.052 & 21251.6 & 2313.4 & 9.2 & $1(4)$ & 0.415 \\
\hline & & 70 & 200.9 & 4092.5 & 0.049 & 10045.0 & 1913.6 & 5.2 & $1(5)$ & 0.510 \\
\hline & 30 & 85 & 245.7 & 5012.4 & 0.049 & 10250.02 & 1952.7 & 5.2 & $1(4)$ & 0.415 \\
\hline & & 97 & 278.9 & 5661.1 & 0.049 & 10506.3 & 1991.8 & 5.3 & $1(4)$ & 0.415 \\
\hline
\end{tabular}

Note; A: Angle, R: Reflectivity, Min.: Minimum Ave.: Average, U: Uniformity factor, L: Luminance contrast.

Table 10. Light shelf angle for lighting energy saving and total lighting energy consumption for Case 3.

\begin{tabular}{|c|c|c|c|c|}
\hline \multirow{2}{*}{ Season } & \multicolumn{2}{|c|}{ Light Shelf Variables for Energy Saving } & \multirow{2}{*}{$\begin{array}{l}\text { Lighting Energy } \\
\text { Consumption (kWh) }\end{array}$} & \multirow{2}{*}{$\begin{array}{l}\text { Total Lighting Energy } \\
\text { Consumption (kWh) }\end{array}$} \\
\hline & Angle & Reflectivity & & \\
\hline Summer & 30 & 97 & 1.799 & \\
\hline Middle season & 30 & 97 & 2.074 & 4.288 \\
\hline Winter & 30 & 97 & 0.415 & \\
\hline
\end{tabular}




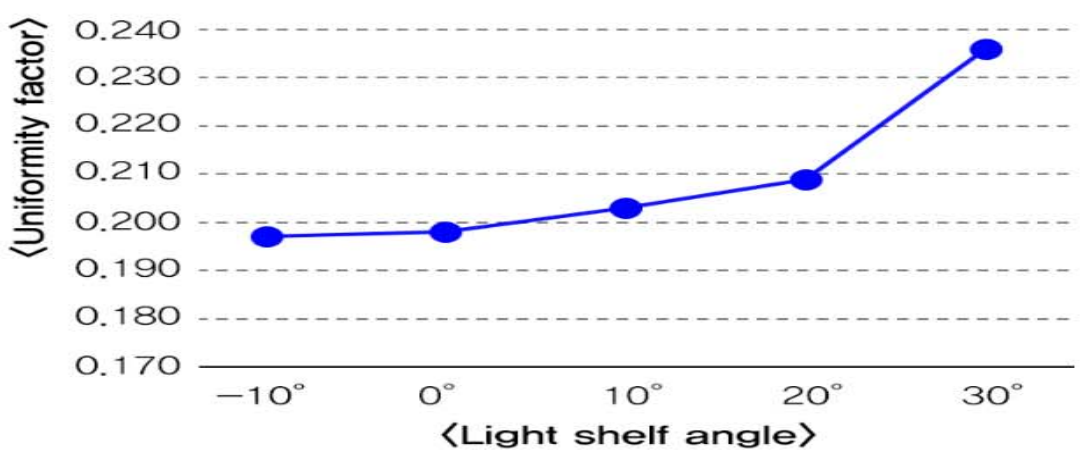

(a)

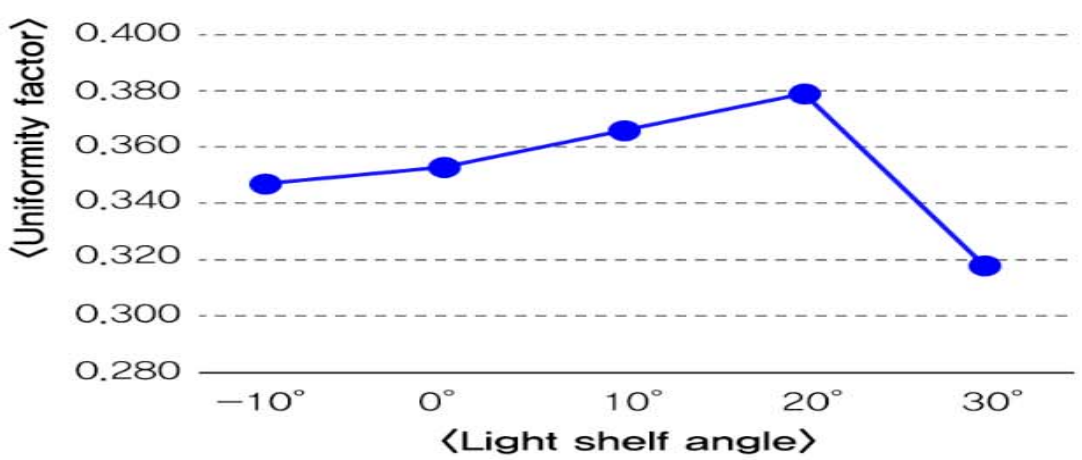

(b)

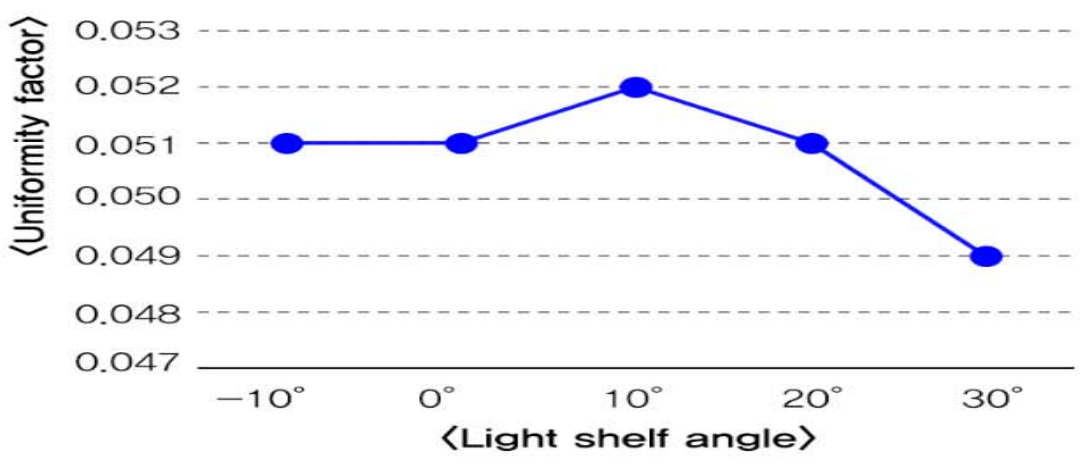

(c)

Figure 8. Analysis of uniformity per light shelf angle: (a) uniformity per light shelf angle in summer; (b) uniformity per light shelf angle in middle season; (c) uniformity per light shelf angle in winter.

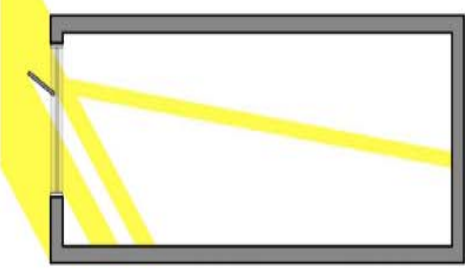

(a)

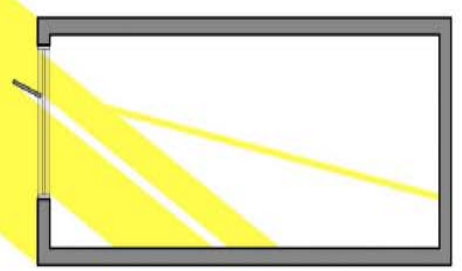

(b)

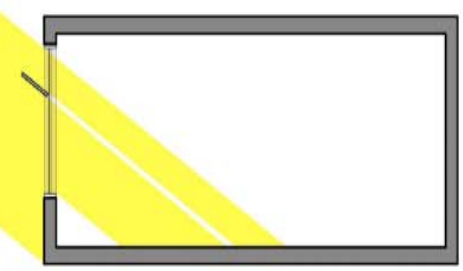

(c)

Figure 9. Diagram of light flow into a room per light shelf angle: (a) light shelf angle $30^{\circ}$ in summer; (b) light shelf angle $20^{\circ}$ in middle season; (c) light shelf angle $30^{\circ}$ in winter. 
Second, the uniformity analysis depending on the light shelf angle is shown in Table 7 and Figure 8 , and the details are as follows. In the summer, increasing the light shelf angle increased the amount of natural light that flows into a room through a light shelf reflection, so the indoor uniformity is improved. Even in the middle season, similar to the summer, the uniformity also improved as the light shelf angle increases. However, when the light shelf angle was $30^{\circ}$, as shown in Figure 9, the natural light that flowed through the light shelf reflection flowed directly onto the work surface without secondary reflection from the ceiling, so illuminance imbalance occurred, and the uniformity fell. Also, in the winter, when the light shelf angle was $20^{\circ}$, the uniformity dropped for the same reason as in the middle season with a light shelf angle of $30^{\circ}$. The angle of $30^{\circ}$ was not suitable for improving uniformity because external natural light entered the lower part of the light shelf reflector.

Third, results of the luminance contrast depending on the light shelf angle, are reported in Table 7 and Figure 10. The light shelf's angle control with a reflectivity of $85 \%$ had a luminance contrast value below 10, so glare was not generated in this condition. However, when the light shelf's reflective surface angle was more than $10^{\circ}$, which is a light shelf angle that makes luminance measurement points exposed for measurement, its luminance contrast value was higher compared to the scenario in which the light shelf angle was $-10^{\circ}$ or $0^{\circ}$. Thus, it is advantageous not to expose the light shelf reflector to occupants by fixing the light shelf's angle to $0^{\circ}$ or less to decrease the luminance contrast value. Also, when the light shelf angle was $30^{\circ}$ for the middle season and $20^{\circ}$ for the winter, the external natural light could be exposed directly to the occupant through light shelf reflection. The luminance contrast value can also be high.

Fourth, as shown in Table 9, the increase of light shelf reflectivity increased the amount of natural light that flowed through light shelf reflection, which was advantageous for improving uniformity. However, as shown in Figure 11, it was unsuitable for improving the visual environment by increasing the luminance contrast. In particular, in the middle season, the condition of glare generation occurs when the light shelf angle was $30^{\circ}$. The reflectivity was $97 \%$, so it gave an unpleasant visual environment to the occupants. Therefore, it should be advantageous to improve building energy saving and the indoor visual environment by appropriately changing the light shelf's reflectivity rather than simply increasing it.

Given the information about uniformity and glare described above, the appropriate standard for light shelf 2 is shown in Table 11. It is different from the standard for a light shelf when only energy saving is considered. In particular, it is possible to improve lighting performance by appropriately changing reflectivity. It should also be effective for improving the visual environment related to uniformity and glare.

Table 11. Analysis of light shelf variables and lighting energy consumption to improve energy saving and visual environment.

\begin{tabular}{cccccc}
\hline \multirow{2}{*}{ Case } & Season & $\begin{array}{c}\text { Light Shelf Variables to Improve Energy } \\
\text { Saving, Uniformity, and Glare }\end{array}$ & $\begin{array}{c}\text { Lighting Energy } \\
\text { Consumption (kWh) }\end{array}$ & $\begin{array}{c}\text { Total Lighting Energy } \\
\text { Consumption (kWh) }\end{array}$ \\
\cline { 3 - 4 } & Angle & Reflectivity & 1.885 & 4.844 \\
\hline \multirow{2}{*}{2} & Summer & 30 & Fixed to 85\% & 2.544 & \\
& Middle season & 20 & & 0.415 & 4.568 \\
& Winter & 10 & $97 \%$ & 1.799 & \\
\hline \multirow{2}{*}{3} & Summer & 30 & $97 \%$ & 0.354 & \\
& Middle season & 20 & $85 \%$ & & \\
\hline
\end{tabular}




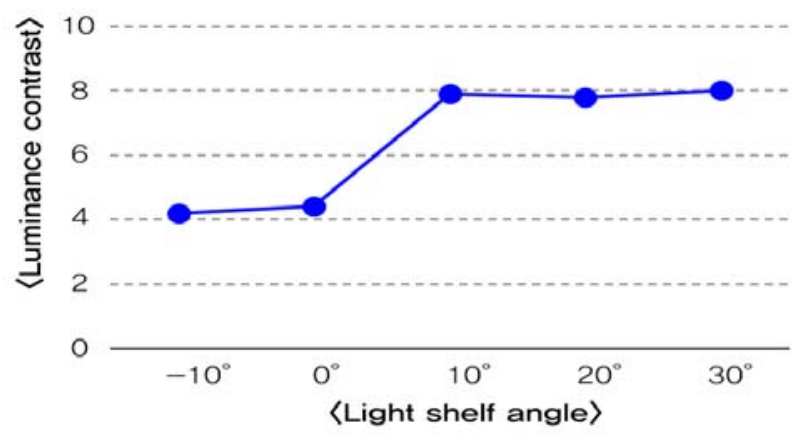

(a)

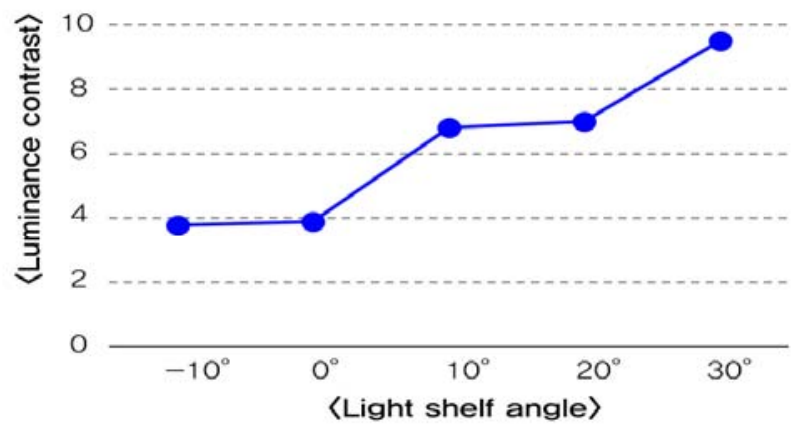

(b)

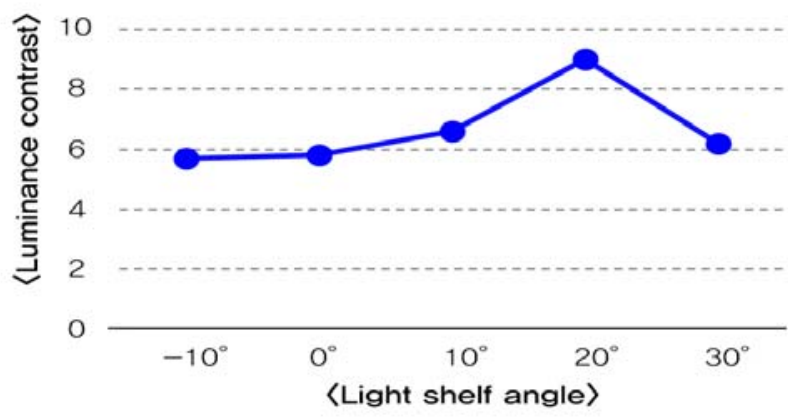

(c)

Figure 10. Analysis of luminance contrast per light shelf angle: (a) per light shelf angle in summer; (b) luminance contrast per light shelf angle in middle season; (c) luminance contrast per light shelf angle in winter.

\subsection{Discussion}

The current study proposes a light shelf with a rolling reflector capable of changing reflectivity and verifies its performance. The results and additional suggestions are discussed in the following.

First, as shown in Figure 12, the light shelf using a rolling reflector that can change its reflectivity (Case 3) showed energy savings of $18.9 \%$ and $7.3 \%$, respectively, over an external light shelf with an angle of $0^{\circ}$ and a reflectivity of $85 \%$ (Case 1) and a movable external light shelf with a reflectivity of $85 \%$ (Case 2). Also, the light shelf with a rolling reflector that can change its reflectivity (Case 3 ) showed an energy savings of $13.6 \%$ and $5.7 \%$, respectively, over the external light shelf with an angle of $0^{\circ}$ and a reflectivity of $85 \%$ (Case 1 ) and the movable external light shelf with a reflectivity of $85 \%$ (Case 2), even when considering lighting energy saving, uniformity, and glare. This data proves the effectiveness of the lighting system proposed in the current study. 


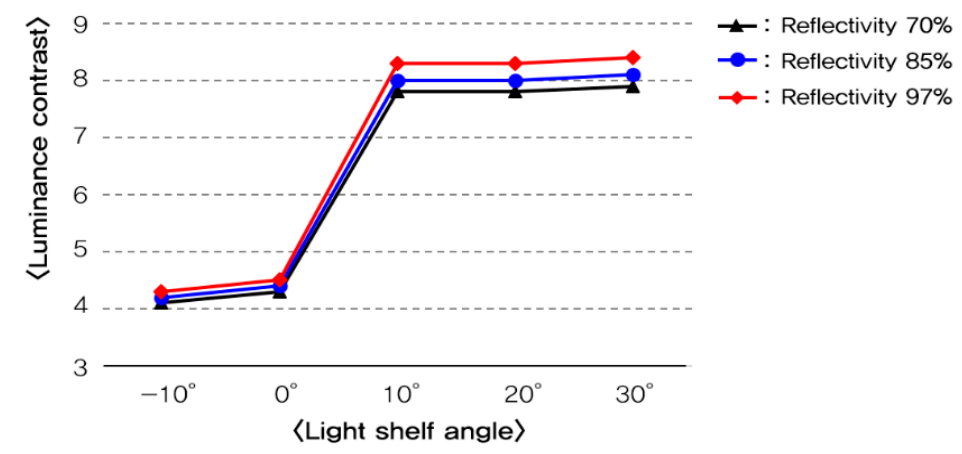

(a)

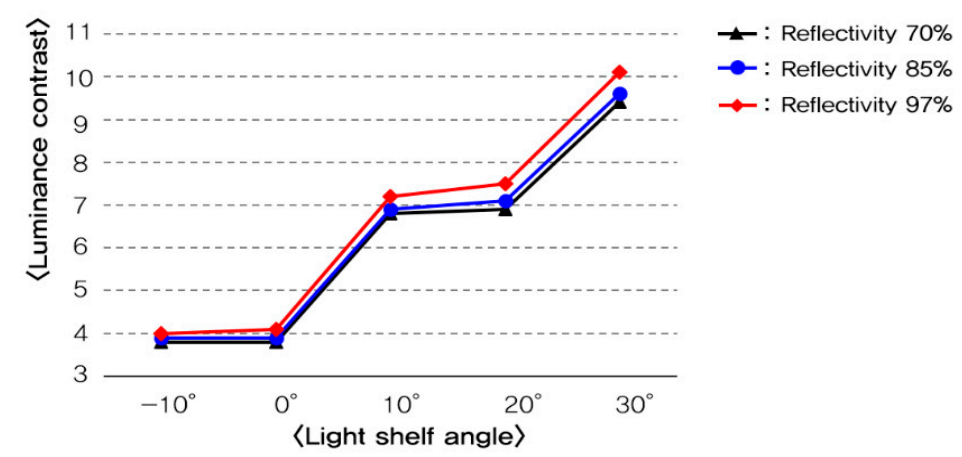

(b)

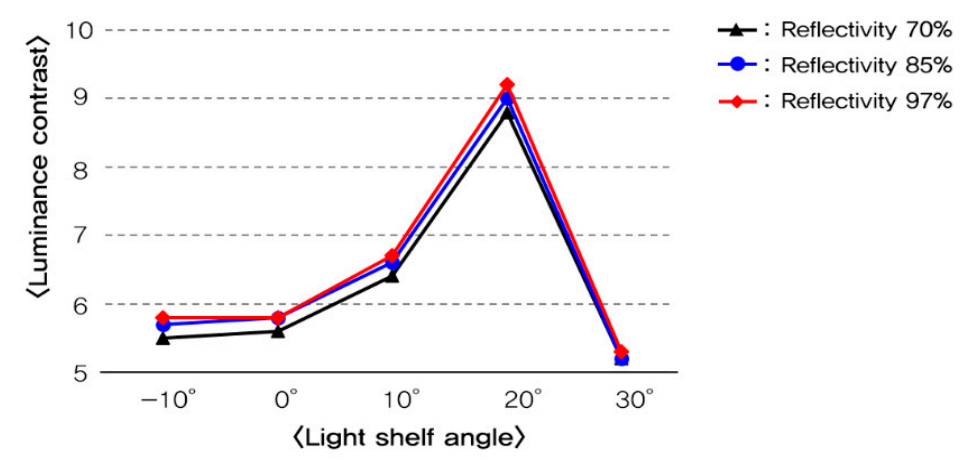

(c)

Figure 11. Analysis of luminance contrast per light shelf angle and reflectivity: (a) luminance contrast per light shelf angle and reflectivity in summer; (b) luminance contrast per light shelf angle and reflectivity in middle season; (c) luminance contrast per light shelf angle and reflectivity in winter.

Second, changing the angle or reflectivity of a light shelf can cause a glare, creating an unpleasant visual environment for occupants. Thus, the following factors should be considered when designing a light shelf. When the light shelf angle is below $0^{\circ}$, the reflective surface is not exposed to occupants, resulting in a decreased luminance contrast value, and there is no glare problem. However, this causes a decrease in lighting performance. The movable light shelf with varied angles and a rolling reflector that can change its reflectivity (Case 3) can solve this problem.

Third, an external type of light shelf has the advantage of excellent performance [27]. However, its lighting performance deteriorates because of the decreased reflectivity caused by soiling. Dust accumulates on the reflector because of exposure to the outside. Therefore, maintenance is important for an external type light shelf, but there are also difficulties compared to an indoor type light shelf. As shown in Figure 13, the light shelf with a rolling reflector that can change its reflectivity, provides a space in the upper and lower sides of the light shelf that allows for installing additional cleaning brushes to partially remove soiling. This helps the light shelf maintain a certain level of lighting 
performance for a longer period. That is, the proposed light shelf with a rolling reflector improves lighting performance, uniformity, and glare, and keeps the light shelf reflector clean. This feature also highlights the effectiveness of the proposed system.

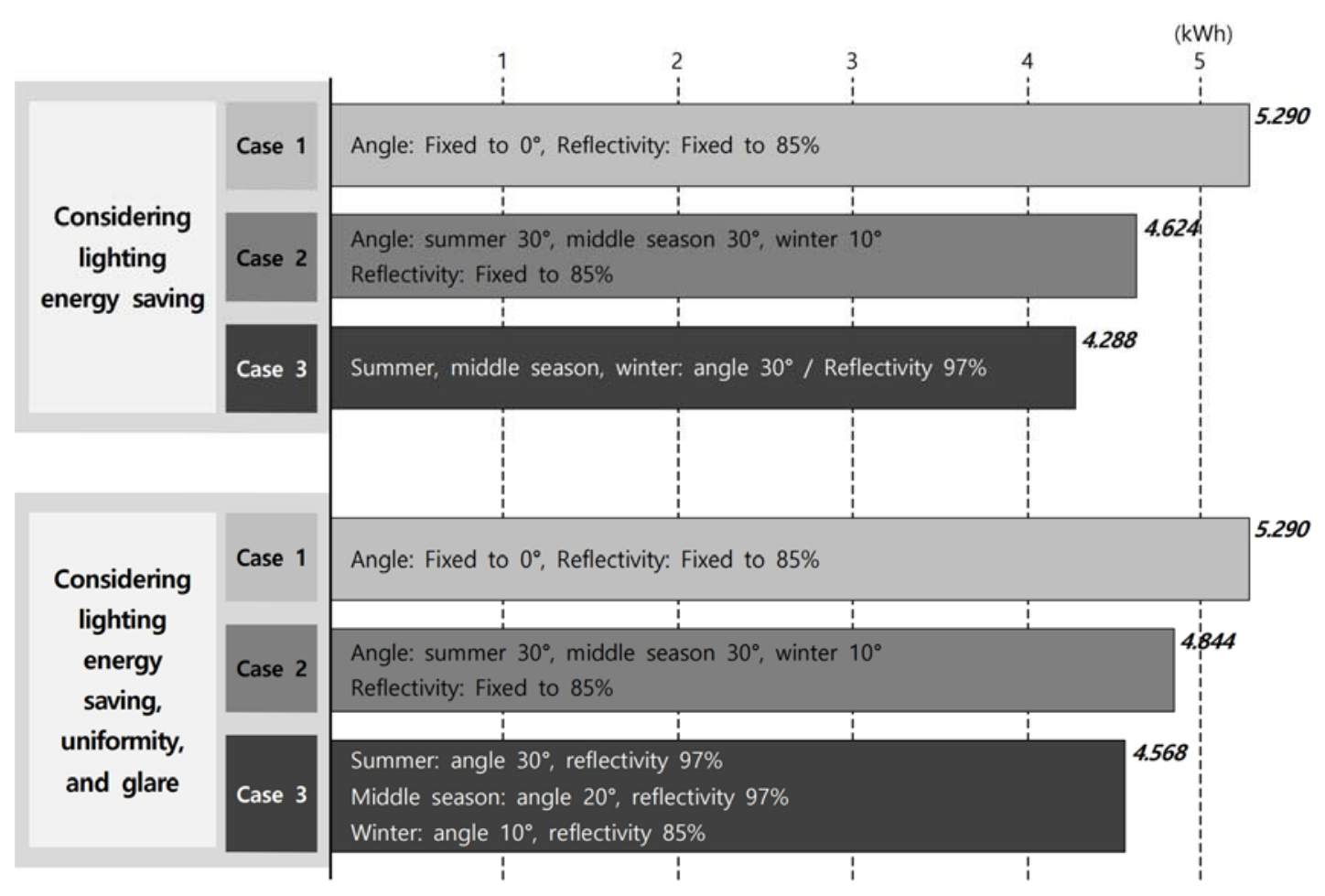

Figure 12. Performance evaluation results by case: total lighting energy usage.

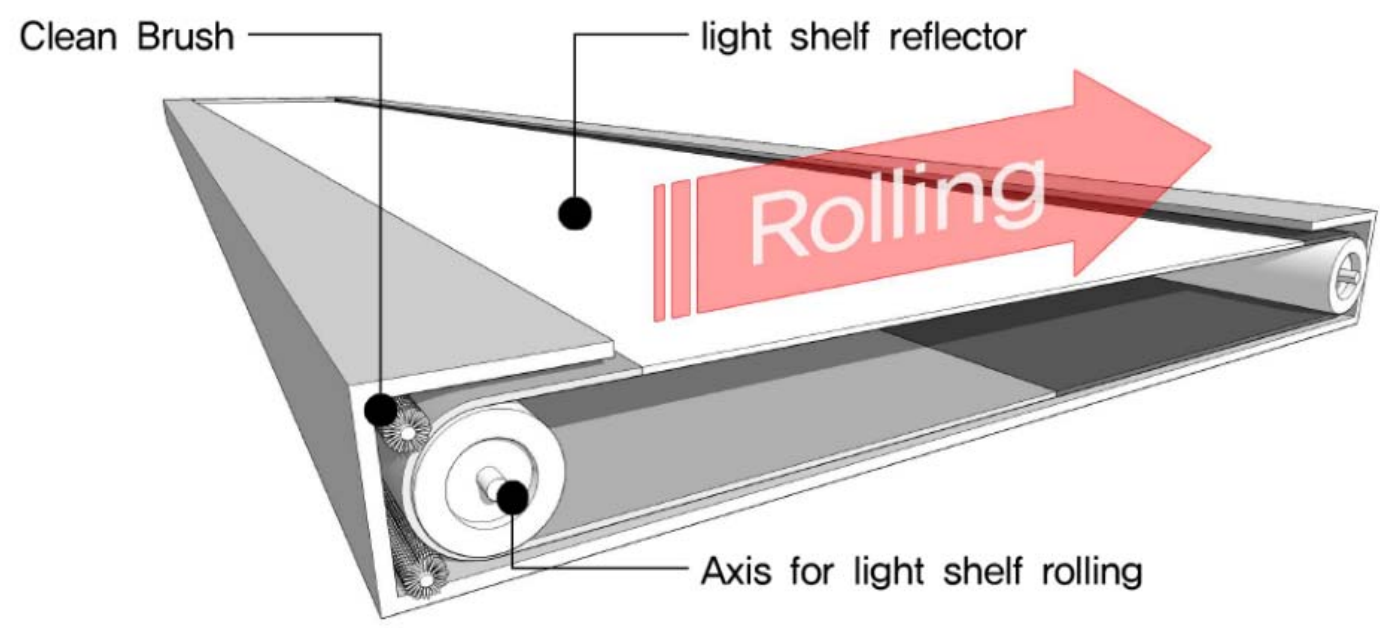

Figure 13. Maintenance of reflector through reflector rolling (application of clean brush system).

\section{Conclusions}

This study proposes a light shelf with a rolling reflector that can change its reflectivity to improve the lighting performance and visual environment and proves its effectiveness by conducting a performance verification. The conclusions are as follows.

First, the light shelf with a rolling reflector has three reflective films with different reflectivity connected and rolls the connected film using two axes. The design makes it possible to change the reflectivity of the light shelf. Also, maintenance of the external type light shelf will be easy because cleaning brushes can be installed on both sides of the light shelf. However, a light shelf with a rolling 
reflector that can change the reflectivity requires a system for rolling, so it has the disadvantage of increasing the shelf's width and thickness.

Second, the increased light shelf angle increases the amount of natural light that flows deep into a room through the light shelf, so the indoor uniformity is improved. The increase in the reflectivity of a light shelf is advantageous in improving indoor uniformity. However, when the light shelf angle is $30^{\circ}$ in the middle season, and the light shelf angle is $20^{\circ}$ in the winter, natural light directly reaches occupants or the work surface through the light shelf's reflection, which lowers uniformity. In addition, natural light does not reach the light shelf reflector in the winter, due to the solar altitude, if the light shelf angle is $30^{\circ}$. Instead, it partially blocks the natural light that can flow into the room, decreasing uniformity. This should be considered when improving the visual environment of an indoor space using a light shelf.

Third, the increase of the light shelf angle increases luminance contrast. In particular, when the light shelf angle is $30^{\circ}$ in the middle season and is $20^{\circ}$ in the winter, natural light directly reaches an occupant through the reflection of a light shelf, which is expected to create an unpleasant visual environment for the occupant. Also, the increased reflectivity increases luminance contrast. The light shelf angle of $30^{\circ}$ and $98 \%$ reflectivity in the middle season causes a glare, but some can be removed by adjusting the reflectivity.

Fourth, it was found that the light shelf with a rolling reflector can reduce energy consumption by $18.9 \%$ and $7.3 \%$, respectively, compared to a typical fixed light shelf and movable light shelf when only lighting energy saving is considered. Also, the light shelf with a rolling reflector that can change its reflectivity can reduce energy consumption by $13.6 \%$ and $5.7 \%$, respectively, compared to a typical fixed light shelf and movable light shelf, even considering lighting energy saving, uniformity, and luminance. This proves the effectiveness of the light shelf with a rolling reflector.

This study verified the improvement of the visual environment according to the reflectivity and operation of a light shelf. The results will serve as a basis for future research to improve the performance of a light shelf, a kind of natural lighting system. However, as a preliminary investigation, there are some limitations to its extended use. The performance evaluation was performed using the south-facing direction only due to the mechanical limitations of the artificial sunlight. An evaluation that considers the azimuth angle of the sun and external illuminance per period, which may occur in an actual environment, should follow. Also, based on the current investigation, it is necessary to verify the applicability and effectiveness of the light shelf with a rolling reflector in terms of its installation cost, operation method, and various reflectivities in varied environmental conditions in the future studies.

Author Contributions: H.L. developed the main idea for the current study. H.L. performed the analysis, interpreted the results, and wrote the manuscript. H.L. reviewed the paper. Author has read and approved the final manuscript.

Funding: This research was funded by a 2020 research Grant from Sangmyung University.

Acknowledgments: None stated.

Conflicts of Interest: The author declare no conflict of interest.

\section{References}

1. He, Y.; Li, N.; Wang, X.; He, M.; He, D. Comfort, Energy Efficiency and Adoption of Personal Cooling Systems in Warm Environments: A Field Experimental Study. Int. J. Environ. Res. Public Health 2017, 14, 1408. [CrossRef] [PubMed]

2. Oh, M.S.; Ahn, J.H.; Kim, D.W.; Jang, D.S.; Kim, Y. Thermal comfort and energy saving in a vehicle compartment using a localized air-conditioning system. Appl. Energy 2014, 133. [CrossRef]

3. Zhang, H.; Arens, E.; Taub, M.; Dickerhoff, D.; Bauman, F.; Fountain, M.; Pasut, W.; Fannon, D.; Zhai, Y.C.; Pigman, M. Using footwarmers in offices for thermal comfort and energy savings. Energy Build. 2015, 104, 233-243. [CrossRef]

4. Zhang, H.; Arens, E.; Zhai, Y. A review of the corrective power of personal comfort systems in non-neutral ambient environments. Build. Environ. 2015, 91. [CrossRef] 
5. Saini, J.; Dutta, M.; Marques, G. Indoor air quality monitoring systems based on Internet of things: A systematic review. Int. J. Environ. Res. Public Health 2020, 17, 4942. [CrossRef]

6. Moreno-Rangel, A.; Sharpe, T.; McGill, G.; Musau, F. Indoor air quality in Passivhaus dwellings: A literature review. Int. J. Environ. Res. Public Health 2020, 17, 4749. [CrossRef]

7. Zhang, R.; Campanella, C.; Aristizabal, S.; Jamrozik, A.; Zhao, J.; Porter, P.; Ly, S.; Bauer, B.A. Impacts of Dynamic LED Lighting on the Well-Being and Experience of Office Occupants. Int. J. Environ. Res. Public Health 2020, 17, 7217. [CrossRef]

8. Energy Efficiency and Renewable Energy. 2018 Renewable Energy Data Book. Available online: https://www. energy.gov/eere/analysis/downloads/2018-renewable-energy-data-book (accessed on 11 October 2020).

9. U.S. Energy Information Administration. Use of Energy Explained. Available online: https://www.eia.gov/ energyexplained/use-of-energy/commercial-buildings.php (accessed on 11 October 2020).

10. Kwon, S.Y.; Lim, J.H. Multi-objective context-adaptive natural lighting system. Energy Build. 2017, 144, 61-73. [CrossRef]

11. Yeh, S.C. A natural lighting system using a prismatic daylight collector. Lighting Res. Technol. 2014, 46, 534-547. [CrossRef]

12. Spacek, A.D.; Neto, J.M.; Biléssimo, L.D.; Junior, O.H.A.; Neto, G.P.D.F.; Giansella, R.D.S.; Santana, M.V.F.D.; Malfatti, C.D.F. Proposal for an experimental methodology for evaluation of natural lighting systems applied in buildings. Energies 2017, 10, 1014. [CrossRef]

13. Soler, A.; Oteiza, P. Dependence on solar elevation of the performance of a light shelf as a potential daylighting device. Renew. Energy 1996, 8, 198-201. [CrossRef]

14. Soler, A.; Oteiza, P. Light shelf performance in Madrid, Spain. Build. Environ. 1997, 32, 87-93. [CrossRef]

15. Claros, S.T.; Soler, A. Indoor daylight climate-comparison between light shelves and overhang performances in Madrid for hours with unit sunshine fraction and realistic values of model reflectance. Sol. Energy 2001, 71, 233-239. [CrossRef]

16. Claros, S.T.; Soler, A. Indoor daylight climate-influence of light shelf and model reflectance on light shelf performance in Madrid for hours with unit sunshine fraction. Build. Environ. 2002, 37, 587-598. [CrossRef]

17. Freewan, A.A.; Shao, L.; Riffat, S.J.S.E. Optimizing performance of the lightshelf by modifying ceiling geometry in highly luminous climates. Sol. Energy 2008, 82, 343-353. [CrossRef]

18. Raphael, B. Active control of daylighting features in buildings. Comput. B Act. Control Daylighting Features 2011, 26, 393-405. [CrossRef]

19. Lim, Y.W.; Ahmad, M.H. The effects of direct sunlight on light shelf performance under tropical sky. Indoor Built Environ. 2015, 24, 788-802. [CrossRef]

20. Lim, Y.W.; Heng, C.Y.S. Dynamic internal light shelf for tropical daylighting in high-rise office buildings. Build. Environ. 2016, 106, 155-166. [CrossRef]

21. Lee, H.; Kim, K.; Seo, J.; Kim, Y. Effectiveness of a perforated light shelf for energy saving. Energy Build. 2017, 144, 144-151. [CrossRef]

22. Berardi, U.; Anaraki, H.K. The benefits of light shelves over the daylight illuminance in office buildings in Toronto. Indoor Built Environ. 2018, 27, 244-262. [CrossRef]

23. Lee, H. Performance evaluation of a light shelf with a solar module based on the solar module attachment area. Build. Environ. 2019, 159, 106161. [CrossRef]

24. Lee, H.; Seo, J.; Choi, C.H. Preliminary Study on the Performance Evaluation of a Light Shelf Based on Reflector Curvature. Energies 2019, 12, 4295. [CrossRef]

25. Meresi, A. Evaluating daylight performance of light shelves combined with external blinds in south-facing classrooms in Athens, Greece. Energy Build. 2016, 116, 190-205. [CrossRef]

26. Mangkuto, R.A.; Feradi, F.; Putra, R.E.; Atmodipoero, R.T.; Favero, F. Optimisation of daylight admission based on modifications of light shelf design parameters. J. Build. Eng. 2018, 18, 195-209. [CrossRef]

27. Moazzeni, M.H.; Ghiabaklou, Z. Investigating the influence of light shelf geometry parameters on daylight performance and visual comfort, a case study of educational space in Tehran, Iran. Buildings 2016, 6, 26. [CrossRef]

28. Al-Sallal, K.A. Easing high brightness and contrast glare problems in universal space design studios in the UAE: Real models testing. Renew. Energy 2006, 31, 617-630. [CrossRef]

29. Lee, H.; Gim, S.; Seo, J.; Kim, Y. Study on movable light-shelf system with location-awareness technology for lighting energy saving. Indoor Built Environ. 2017, 26, 796-812. [CrossRef] 
30. Kim, K.; Lee, H.; Jang, H.; Park, C.; Choi, C. Energy-saving performance of light shelves under the application of user-awareness technology and light-dimming control. Sustain. Cities Soc. 2019, 44, 582-596. [CrossRef]

31. Hopkinson, R.G. Glare from daylighting in buildings. Appl. Ergon. 1972, 3, 206-215. [CrossRef]

32. Cantin, F.; Dubois, M.C. Daylighting metrics based on illuminance, distribution, glare and directivity. Lighting Res. Technol. 2011, 43, 291-307. [CrossRef]

33. Mattoni, B.; Gori, P.; Bisegna, F. A step towards the optimization of the indoor luminous environment by genetic algorithms. Indoor Built Environ. 2017, 26, 590-607. [CrossRef]

34. Illuminating Engineering Society. The Lighting Handbook, 10th ed.; Illuminating Engineering Society (IES): New York, NY, USA, 2011.

35. ISZ. Recommended Levels of Illumination; Japanese Industrial Standards Committee: Tokyo, Japan, 2010.

36. KSA. Jap Recommended Levels of Illumination; The Korean Standards Association (KSA): Seoul, Korea, 1998.

37. Abdou, O.A. Effects of luminous environment on worker productivity in building spaces. J. Archit. Eng. 1997, 3, 124-132. [CrossRef]

38. Szokolay, S.V. Environmental Science Handbook for Architects and Builders; Construction Press: London, UK, 1980; Volume 532, pp. 91-143.

39. Zhejiang Pengyuan New Material Co., Ltd. Flexible Reflective Film for Packaging Metallized Film Material. Available online: https://hzpengyuan.en.made-in-china.com/product/eCXQdhOcwEkK/China-FlexibleReflective-Film-for-Packaging-Metallized-Film-Material.html (accessed on 11 October 2020).

40. ASTM International. Standard Classification for Solar Simulators for Electrical Performance Testing of Photovoltaic Devices. Available online: https://www.astm.org/Standards/E927.htm (accessed on 11 October 2020).

41. Jung, B.K.; Choi, A.S. An experimental study of the optimum spatial characteristics and location of photosensor for daylight responsive dimming systems. J. Korean Inst. Illum. Electr. Install. Eng. 2003, 17, 8-14. [CrossRef]

Publisher's Note: MDPI stays neutral with regard to jurisdictional claims in published maps and institutional affiliations.

(C) 2020 by the author. Licensee MDPI, Basel, Switzerland. This article is an open access article distributed under the terms and conditions of the Creative Commons Attribution (CC BY) license (http://creativecommons.org/licenses/by/4.0/). 